\title{
The impact of pest risk management measures on trade: the case of apples from France and Chile
}

\author{
DeMaria Federica', Drogue Sophie ${ }^{2^{*}}$ and Lubello Pasquale ${ }^{2}$
}

\author{
*Correspondence: sophie.drogue@ \\ inrae.fr \\ ${ }^{2}$ UMR MoISA, Univ Montpellier, CIRA \\ D, CIHEAM-IAMM, INRAE, Institut \\ Agro, 2 place Pierre-Viala-Bât. 26, \\ 34060 Montpellier Cedex 2, France \\ Full list of author information is \\ available at the end of the article
}

\begin{abstract}
In this article, we investigate how pest risk management protocols may affect trade flows of fresh apples. We apply our analysis to two major players in the international trade of fresh apples: France and Chile. These two countries have been chosen because they are among the world's leading apple exporters and although they have similar market shares, they differ in terms of destination markets, seasonality, local conditions and export strategy. In order to assess the impact of pest risk management protocols on international trade of apples from France and Chile, we introduce in a gravity equation beside the traditional variables, a score able to measure their complexity. The results are interesting in the sense that even if the score for France and Chile by main trading partners are rather close, we found that French apples exporters would be more impacted by pest risk management protocols than their Chilean counterparts.

Keywords: SPS measures, International trade, France, Chile, Gravity Modelling, Apples JEL Classification codes: Q17, F13
\end{abstract}

\section{Introduction}

A large strand of the literature in international trade is devoted to assess the impact of sanitary and phytosanitary (SPS) measures and technical regulations on trade (see Beghin 2017; Zezza et al. 2018). SPS measures are those defined in the Article 1.1, Article 1.2 and Annex A of the SPS Agreement "SPS measures include all relevant laws, decrees, regulations, requirements, and procedures including, among others: end product criteria; processes and production methods; testing, inspection, certification, and approval procedures; quarantine treatments, including relevant requirements associated with the transport of animals or plants, or with the materials necessary for their survival during transport; provisions on relevant statistical methods, sampling procedures, and methods of risk assessment; and packaging and labelling requirements directly related to food safety". They are those measures classified in the chapters A, B and $\mathrm{C}$ of the United Nation Conference on Trade and Development (UNCTAD)'s international classification of non-tariff measures (see Table 4 in Appendix).

(c) The Author(s). 2021 Open Access This article is licensed under a Creative Commons Attribution 4.0 International License, which permits use, sharing, adaptation, distribution and reproduction in any medium or format, as long as you give appropriate credit to the original author(s) and the source, provide a link to the Creative Commons licence, and indicate if changes were made. The images or other third party material in this article are included in the article's Creative Commons licence, unless indicated otherwise in a credit line to the material. If material is not included in the article's Creative Commons licence and your intended use is not permitted by statutory regulation or exceeds the permitted use, you will need to obtain permission directly from the copyright holder. To view a copy of this licence, visit http://creativecommons.org/licenses/by/4.0/. 
In the case of fresh vegetable products, trade is governed by two types of SPS measures, those protecting humans' health and those protecting plants' health.

Those concerning humans, as for example food safety standards like Maximum Residual Levels (MRL) of any contaminant, apply indiscriminately to domestic and foreign producers. The only divergence is that each country is free to adopt its own standard (Carrère et al. 2018). Those concerning plants (whether for crops or indigenous species' protection) are often supply-source-specific because as specified by the SPS Agreement in Article 2.3, the principle of non-discrimination prevails only between members having identical or similar conditions.

Regarding pest and disease risk management, phytosanitary protocols, i.e. the phytosanitary requirements, the inspections and procedures to be carried out, the sampling procedures for inspection and all the administrative paperwork to be dealt with, are not only set by each country independently but they also discriminate between domestic and foreign producers and also between foreign producers (Roberts 1999). Moreover, the complexity of the procedures can vary greatly over time because a country may be affected by a pest or a disease under particular climatic conditions (as it is the case for the Mediterranean fly).

Therefore, these kinds of regulatory measures affect both equity and efficiency. They enhance economic efficiency because they prevent production losses, improve consumer's information and trust and decrease asymmetries but they may redistribute rents to more efficient sectors or producers (Swinnen 2016). They, particularly affect the equity between trade partners because the differences they may induce in the costs of compliance, affect the competitiveness of suppliers, causing a redistribution of the market shares (Fischer and Serra 2000) and may impact producers particularly those who cannot afford complying with the measures.

This asymmetry of treatment directly impacts the costs of production and exportation. (Cadot and Gourdon 2014) showed that Non-Tariff Measures (NTM) of type A and B (see Table 4 in "Appendix" section) have a positive impact on prices equivalent to a tariff of 15\%; (Cadot et al. 2015) established that SPS measures have a positive impact on exports unit value and (Crivelli and Groeschl 2016) concluded that conformity assessmentrelated SPS measures act as a barrier to market entry. But, if the domestic standard is similar to the foreign one, producers have already coped with the cost of compliance and export costs are lower (Vigani et al. 2012 p. 417). This conclusion is confirmed by many authors; (Ragasa et al. 2017) showed for Philippines seafood processors that coping with the European Union (EU)'s Hazard Analysis Critical Control Point (HACCP) certification reduced the costs of meeting the requirements of other export markets. (de Frahan and Vancauteren 2006) assessed that harmonisation of food regulations can have a positive impact on EU imports and particularly on markets penetration.

Consequently, regulatory divergence is taking increasing importance in the trade policy debate and pros-free-trade advocate for harmonisation of standards between countries and alignment on international regulations like those of the Codex Alimentarius. But despite major advances in standards rapprochement (transparency, mutual recognition, harmonisation), asymmetries or heterogeneity in phytosanitary procedures are still more the rule than the exception (Zezza et al. 2018).

In this context, the impact of pest risk management protocols is particularly interesting to assess as it can incentivise policymakers in negotiating bilateral or multilateral 
agreements on phytosanitary requirements which reduce the length of export procedures.

In this article we are interested in assessing the impact of phytosanitary protocols for pest and diseases management on trade of apples from France and Chile.

To perform our analysis, we use the synthetic score developed by (DeMaria et al. 2018). This score takes into account the complexity of pest and disease risk management protocols established by Chile's and France's trading partners. We introduce the score in a gravity equation to assess the pest and disease risk management protocols impact on apples trade of both countries under scrutiny. The rest of the article is organised as follow. The "Background" section presents some stylised fact on the world apples sector and proceeds with a literature review on phytosanitary regulations in apples trade. The "Method" section describes the phytosanitary score, the data and the specification of the model. Results and discussion are presented in a third section. The "Conclusion" section concludes.

\section{Background}

With the movement of global liberalisation in the agrifood sector, trade flows have increased and are accompanied by the emergence of pests in countries previously pestfree. According to (Pimentel et al. 2005), approximately 50,000 non indigenous species in the USA caused major environmental damage and losses totalled approximately $\$ 137$ billion per year. The cost of losses and control of invasive species in the USA, British Isles, Australia, New Zealand, South Africa, India, and Brazil is estimated to more than $\$ 300$ billion per year (Pimentel 2011).

As a consequence, in the sector of fresh produces, many countries have elaborated a set of "good practices" in order to protect themselves from pest and diseases invasion. These practices are based on a pest risk analysis (PRA) in order to identify the necessary phytosanitary protocols to prevent the introduction of the plague. In this field, the International Plant Protection Convention (IPPC) according to International Standards for Phytosanitary Measures No. 11 (FAO 2013), proposes a systems approach to conduct the PRA. This approach is composed of three stages: initiation, pest risk assessment and pest risk management. The initiation stage is mainly based on gathering information and documentation. The pest risk assessment results in a list of pest concerns associated with a commodity and the economic and environmental consequences of the invasion. The third stage describes the measures to be implemented.

In this context, the case of apples is particularly interesting because this fruit is one of the most traded in the world; it is produced by both hemispheres and by developed as well as developing countries (see Fig. 1, 2 and 3).

During transport, apples can carry a number of pests (codling moth, fire blight, sawfly insects, tortricid, aphids and fruit tree spider mites) and fungal (apple scab-Venturia inaequalis and powdery mildew-Podosphaera leucotricha) or viral diseases which can cause damages in orchards and financial losses in the countries of destination. (Zhao et al. 2007) have computed the economic impact of mitigating the apple maggot spread in the State of Washington and estimated the welfare losses for the US apple industry of a spread of this pest to $\$ 4-\$ 8$ million per year.

Even if countries are sovereign in the decision of their phytosanitary protocols, actually most countries have adopted the United State Department of Agriculture (USDA) 


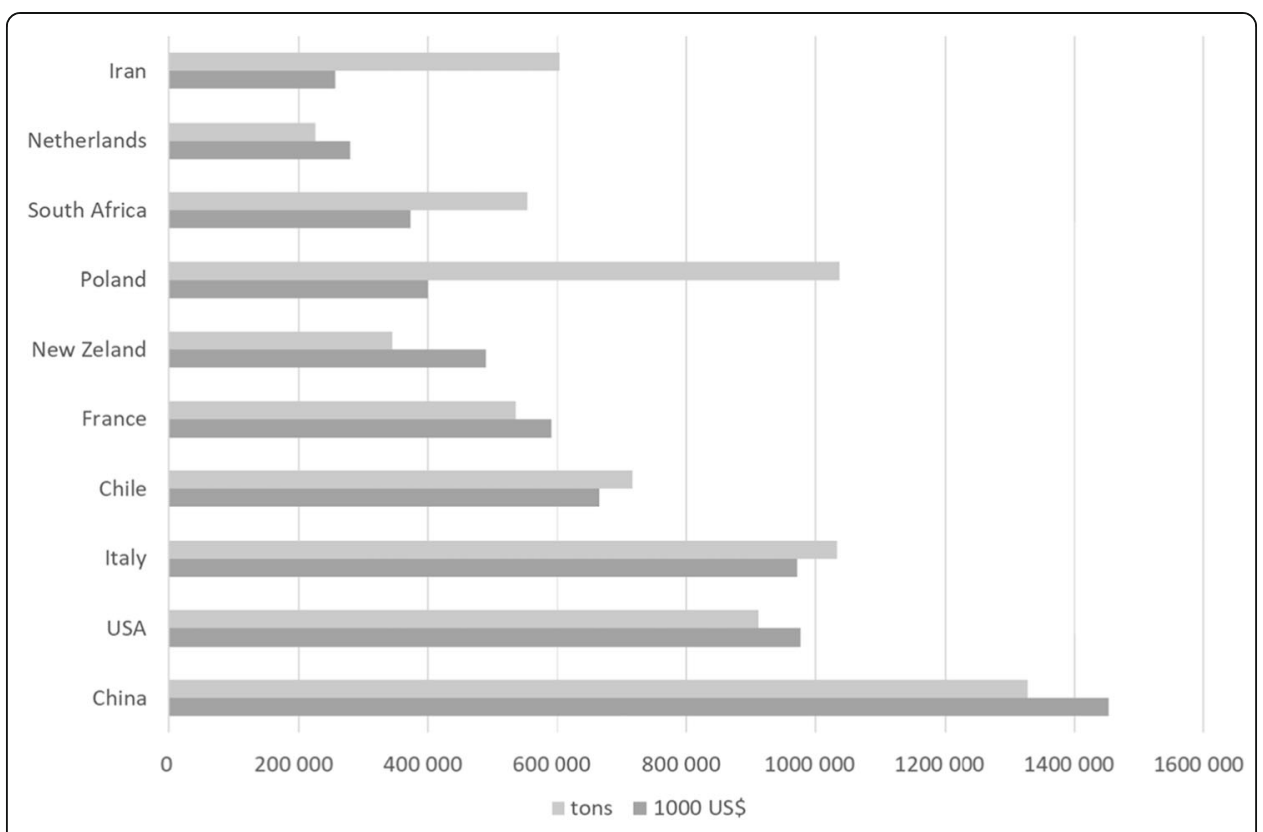

Fig. 1 Top 10 of the world apples exporters in 2017.

Source: FAOSTAT

Animal and Plant Health Inspection Service (APHIS) recommendations (Calvin and Krissoff 1998; APHIS USDA 2014). Concerning apples, the procedures recommended by the USDA APHIS to get rid of most plagues are cold storage and/or fumigation with Methyl Bromid. In addition to these two (rather well established) operations, there are also several administrative procedures (phytosanitary certificate, import permits, preclearance, inspection, etc.), thoroughly described in (DeMaria et al. 2018), which can

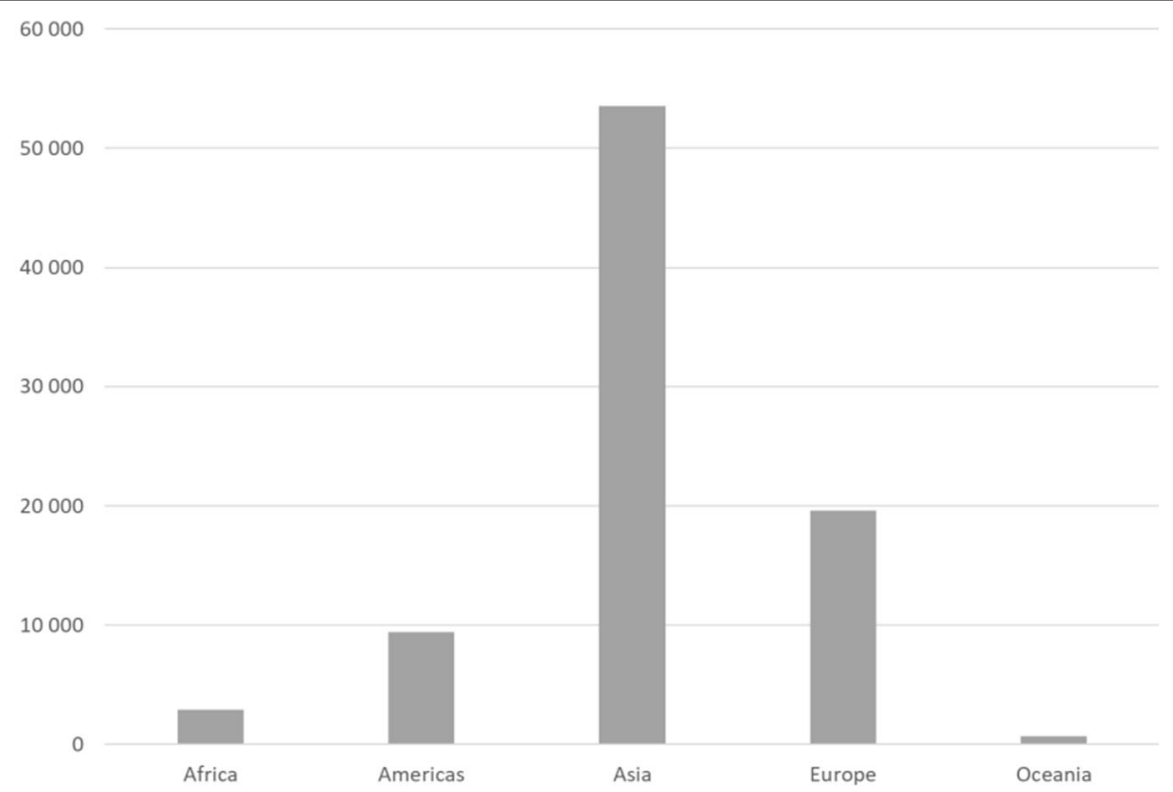

Fig. 2 World apples production by region in 2018. Source FAOSTAT 


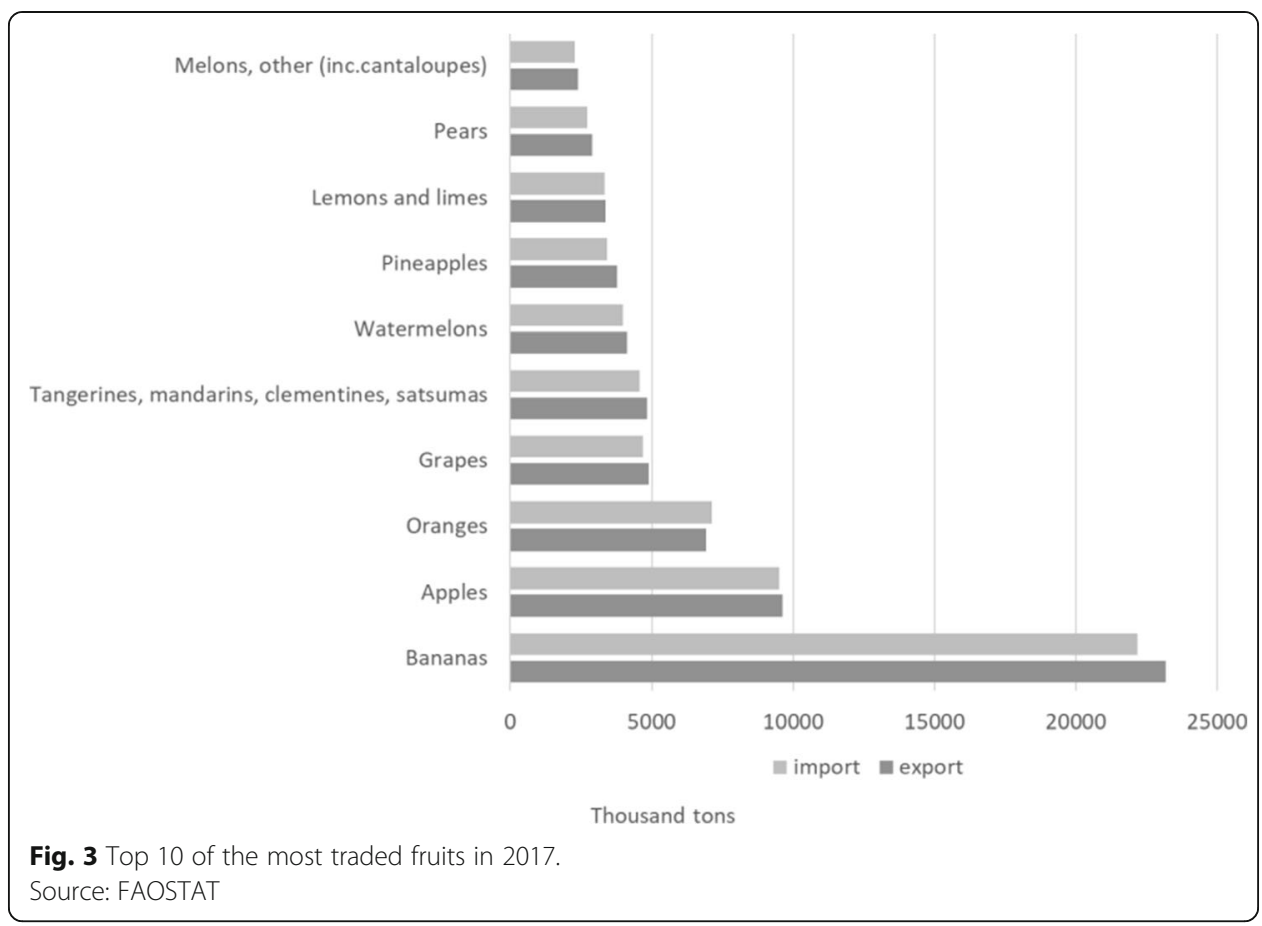

diverge greatly from one country to another. As for example, Tunisia bans imports of apples from the EU; Brazil authorises the importation of apples for consumption from four EU member's states only (France, Italy, Portugal and Spain) whereas the EU's 27 states have harmonised their import procedures and impose the same protocol to all its providers. The too restrictive Japanese sanitary protocol on fire blight prohibited the entry of US Fuji apples and generated long-lasting disputes (Calvin and Krissoff 1998; Calvin et al. 2008).

Some may argue that these constraints constitute real barriers to trade while others oppose that without these requisites, apples could not be shipped anyway.(Calvin et al. 2008): 131) computed that the economic cost induced by the Japanese protocol of mitigating fire blight and codling moth imposed to US Fuji apples was estimated at 15 cents per pound, much higher than the accounting cost of 5 cents per pound (...). (Devadoss et al. 2009) have shown the importance of transport (and by extension) transaction costs and the interlinkages of prices in the world markets in determining apples trade flows. (Drogue and DeMaria 2012) using a gravity model showed that the impact of MRL on the bilateral trade of apples and pears for a dataset of 40 countries can be positive for some exporters. (Melo et al. 2014) used a multidimensional index based on (Engler et al. 2012) study to assess the impact of stringency perception of the Chile's apples trade. They showed that the stringency of phytosanitary standards is detrimental for trade.

Our study contributes to the literature because it compares two different markets and allows disentangling the impact of a particular category of SPS measures, which are those related to the diseases and pest management thanks to a gravity modelling. The originality of our work compared to that of (Calvin and Krissoff 1998) or (Calvin et al. 2008) is that we introduced into our analysis a set of pest and disease risk management protocols for a large number of importers and we evaluated their impact for 
two producing countries. We improve the work of (Engler et al. 2012) and (Melo et al. 2014) as they used qualitative surveys to analyse the perception of standards stringency from Chilean exporters of apples whereas using the score proposed by (DeMaria et al. 2018) allows us to introduce the objective stringency of the standards into our analysis.

Chile and France have been chosen because these two countries are great apples producers and exporters (they are respectively the 4th and 5th world exporters) but which profile is completely different. France produces apples mainly for its domestic market while Chile is totally export-oriented, being located in the Southern hemisphere Chile produces off-season. The total area dedicated to apple is similar in Chile and France (around 40,000 ha) but the average size of apple orchard is 14 ha in France and greater than 100 ha in Chile (figures given by ANPP the French Association for Apples and Pears). In addition, France, more than Chile is affected by standards in force in the apples sector (Codron and Pavez 2018).

\section{Method}

As aforementioned these kind of standards are particularly interesting to analyse as they are country-specific and bilateral negotiations of phytosanitary protocols are crucial in reducing transaction cost and accessing new markets (Zezza et al. 2018). For instance, in the case of apples, the procedure in use against the Mediterranean fly is the one recommended by the USDA despite France's attempts to adopt a different and less costly standard (Lubello et al. 2019). These kinds of requisites represent a challenge for measurement and assessment due to the proliferation of technical and sanitary regulations and standards and to the increasing complexity of the rules. Moreover, the information is qualitative, not always available, often incomplete and not universal.

\section{The phytosanitary score}

In our study, the complexity of the overall phytosanitary protocols imposed to French and Chilean apples exporters is captured by a score, hereafter Phytosanitary Score (PS). It is a two-stage metric described in details in (DeMaria et al. 2018). This score is designed as the sum of the "grade" (Phyto in Eq. 4) obtained by each phytosanitary constraints (called "dimension") imposed by the importing country to the exporting one. (DeMaria et al. 2018) identified 9 dimensions, including the obligation for exporter to obtain an import permit, to carry out a pre-inspection before shipping or an in-transit cold treatment, etc. (see Table 5 in the "Appendix" section). Grades vary between 0 (minPhyto which means the absence of requisite) to 2, 3 or 4 (maxPhyto which considers the existence of a ban) according to the severity of the constraint imposed by the importing country. Moreover, the PS imposes a convexity in the requirements and traduces that there is more difficulty to comply with more demanding requirements (see Eq. 1).

$$
P S_{i j}=\frac{1}{N}\left[\sum_{n=1}^{N} \exp \left(\frac{\text { Phyto }_{i j n}-\text { minPhyto }_{n}}{\text { maxPhyto }_{n}-\text { minPhyto }_{n}}\right)\right]
$$

Here, $P S_{i j}$ measures the complexity of the phytosanitary protocols imposed by importer $j$ to exporter $i$; maxPhyto $_{n}$ is the highest grade in the sub-dimension $n$; Phyto is the grade of the requirement imposed by country $j$ in the dimension $n$ to exporter $i$; 
minPhyto $_{n}$ is the lowest grade in the sub-dimension $n$. The PS is between 1 and $e \approx$ 2.72; a score equal to 2.72 means the imposition of a ban from the importer, while a value of 1 indicates that the country of destination imposes the simplest protocol (see Fig. 4a, b).

PS values for Chile and France are displayed in Fig. 4a, b. Despite a larger sample of partner countries for France than for Chile, some similarities can be observed in the results. First, for both France and Chile, it seems to be easier (low PS value) to export to European countries than to export to the Far East countries (China, Taiwan) or USA (high PS value). Second, the mean and standard deviation of the $P S$ value are almost equal for both countries indicating that they are submitted to the same level of requirements. Moreover, without considering the existing bans, the level of requirements is rather homogeneous with little variability across countries. However, Chile is more successful than France in exporting to more demanding markets as USA or Asia (Codron and Pavez 2018). In this context, it is

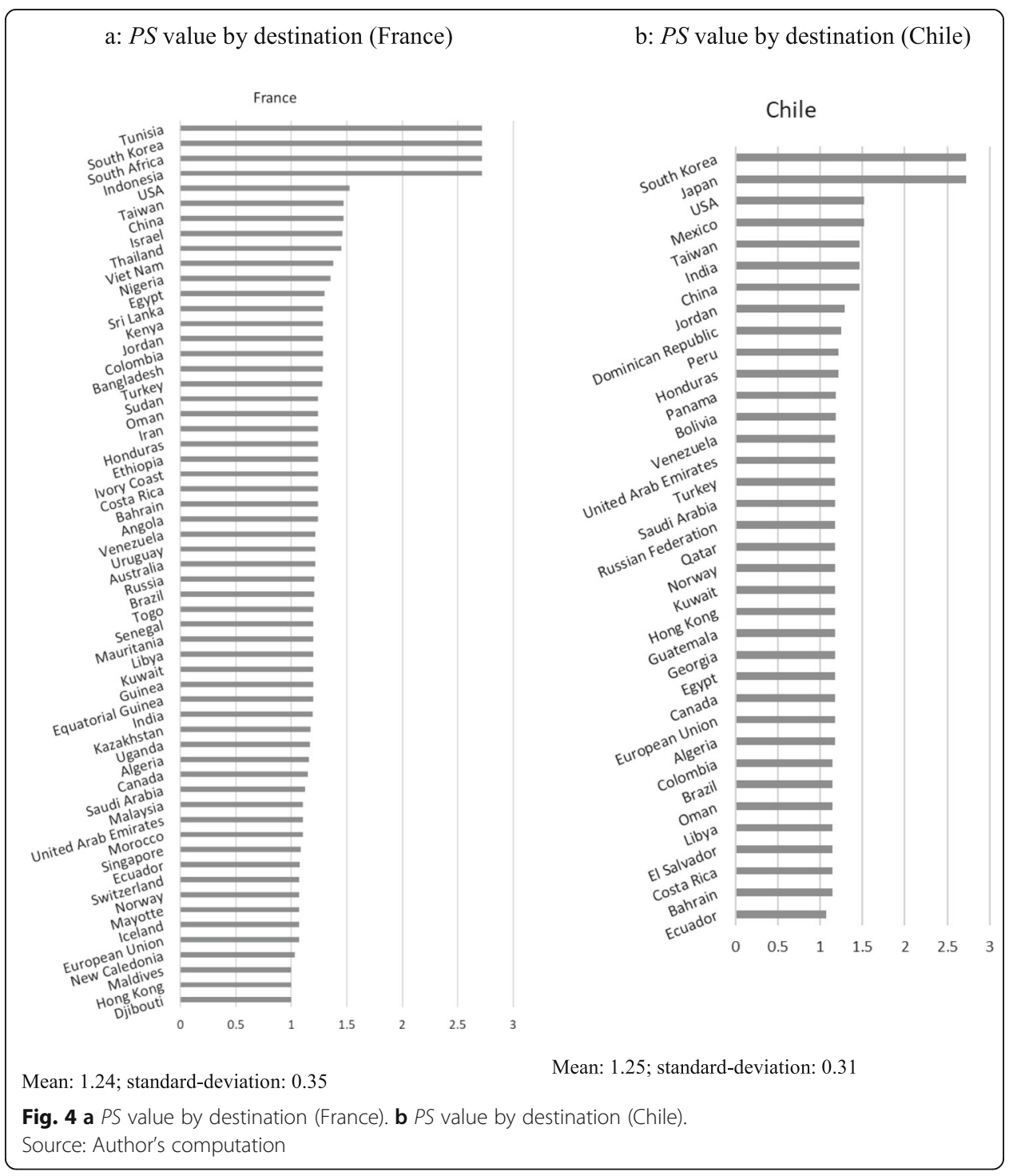


questionable to what extent pest risk management measures may be one of the reasons for this difference.

\section{Data and model specification}

Quantifying the impact of SPS and technical regulations implies to compare the costs and benefits they induce. The methodologies at hand in this area are largely described by (Beghin and Bureau 2001) and gravity modelling is one of them.

The gravity model is a tool widely used in the analysis of international trade. It explains the trade interactions between countries (Anderson 2011); and helps to understand the determinants of trade in terms of quantity, direction and composition. It is based on Newton's law of gravity according to which the force of attraction between two objects is directly proportional to their masses (economic sizes proxied by the Gross Domestic Products, GDP) and inversely proportional to their distance (geographical distance between countries). In order to analyse the impact of PS on trade from France and Chile, we use various gravity specifications.

Our first specification in semi-logarithm form is performed on the whole sample and is written as follows:

$$
\begin{aligned}
X_{i j t}= & \beta_{0}+\beta_{1} \ln G D P_{i t}+\beta_{2} \ln G D P_{j t}+\beta_{3} \ln \text { Distance }_{i j} \\
& +\beta_{4} \ln \text { Applied_Tariff }_{i j t}+\beta_{5} P S_{i j}+\beta_{6} \text { Border }_{i j}+f e_{i}+f e_{j}+f e_{t}+f_{i j t}
\end{aligned}
$$

where $i$ stands for exporter (here France and Chile), $j$ for importer (see list of countries in Table 6 in "Appendix" section) and $t$ for time.

$X_{i j t}$ is the export flow of apples (code 080810 of the 6-digit classification of the Harmonised System) in US\$ from France and Chile to country $j$ between 2006 and 2014. As suggested by

(De Benedictis and Taglioni 2011), this variable is in nominal value. Data are from the United Nations database on trade (UN COMTRADE). $G D P_{i t}$ and $G D P_{j t}$ are respectively the exporter and the importer Gross Domestic Product per capita in year $t$. They have been retrieved from the World Development Indicators of the World Bank. The beta coefficients of these variables are expected to be positive.

Distance $_{i j}$ is the weighted measure of distance between the capitals of Chile or France and country $j$. This variable is a proxy of transport costs. The coefficient estimate of distance is expected to be negative. Border $i j$ is a dummy variable equal to 1 if a country pair shares the same border and 0 otherwise. This beta coefficient is expected to be positive. These variables come from the Centre d'Etudes Prospectives et d'Informations Internationales (CEPII). Applied_Tariff $f_{i j t}$ is equal to 1 plus the ad-valorem applied tariff rate imposed by country $j$ on apples imports from country $i$. Tariffs were retrieved from the Market Access Map (MAcMap) database of the CEPII.

$P S_{i j}$ is the phytosanitary score already presented. $P S_{i j}$ is time invariant for all $t$ because it does not change over time. The sign of its coefficient is not expected a priori but the intuition suggests that it should be negative because the higher the score the more difficult to comply with the requirements of the importing country and therefore the lesser the trade.

The terms $f e_{\dot{\nu}} f e_{j}$ and $f e_{t}$ are the exporter, importer and time fixed effects, respectively. Fixed effects provide a solution to unobserved heterogeneity and account for 
multilateral resistance terms they also provide a more consistent specification (Baldwin and Taglioni 2006).

Finally, $f_{i j t}$ is the error term that is assumed to be normally distributed with zero mean.

Table 1 reports the descriptive statistics of our variables of interest. The time period for the analysis (2006-2014) has been chosen respectively to the availability of data concerning pest risk management in the two countries.

The second specification replicates Eq. (2) but adds an interaction term between the $P S$ and the country $i$ dummy $\left(D_{u m m}\right)_{i}$ ) which is equal to 1 if $i$ is equal to France and 0 for Chile. This allows us to disentangle the effects by exporter.

$$
\begin{aligned}
X_{i j t}= & \alpha+\beta_{1} \ln G D P_{i t}+\beta_{2} \ln G D P_{j t}+\beta_{3} \ln \text { Distance }_{i j} \\
& +\beta_{4} \ln \text { Applied_Tariff }_{i j t}+\beta_{5} P S_{i j}+\beta_{6} \text { Border }_{i j}+\beta_{7} \text { Dummy }_{i} \\
& +\beta_{8} \text { PS }_{i j} * \text { Dummy }_{i}+f e_{j}+f e_{t}+f_{i j t}
\end{aligned}
$$

A third specification (see Eq. 4) adds to Eq. (2) an interaction between the variable $P S$ and five regions reg dummies $\left(D u m m y_{\text {reg }}\right)$. The five regions are Africa $(A F)$, Europe $(E U)$, America $(A M)$, East Asia and Australia $(A A)$, "Western" Asia $(A A)$, see Table 6 in Appendix for the composition of regions. Dummy reg is equal to 1 if country $i$ belongs to $W A$ and 0 otherwise.

$$
\begin{aligned}
X_{i j t}= & \alpha+\beta_{1} \ln G D P_{i t}+\beta_{2} \ln G D P_{j t}+\beta_{3} \ln \text { Distance }_{i j} \\
& +\beta_{4} \text { lnApplied_Tariff }_{i j t}+\beta_{5} P S_{i j}+\beta_{6} \text { Border }_{i j}+\beta_{7} \text { Dummy }_{\text {reg }} \\
& +\beta_{8} P S_{i j} * \text { Dummy }_{\text {reg }}+f e_{i}+f e_{t}+f_{i j t}
\end{aligned}
$$

We also consider Chile and France separately in the analysis; in this case, the specification of the model assumes the following form:

$$
\begin{aligned}
X_{i j t}= & \alpha+\beta_{1} \ln G D P_{j t}+\beta_{2} \ln \text { Distance }_{i j}+\beta_{3} \text { lnApplied_Tariff }_{i j t}+\beta_{4} P S_{i j} \\
& +\beta_{5} \text { Border }_{i j}+f e_{j}+f e_{t}+f_{i j t}
\end{aligned}
$$

From a methodological point of view, in estimating the gravity model, we take into account the potential sources of bias and the presence of zero trade flows (Silva and Tenreyro 2006; Helpman et al. 2008; Burger et al. 2009) which may be a result of economic decision-making based on the potential benefits or costs of trading. The treatment of zeros is an important issue because the improper handling of zeros causes

Table 1 Summary statistics of variables used in the gravity equation

\begin{tabular}{llllll}
\hline Variable & Obs & Mean & Std. dev. & Min & Max \\
\hline$X_{i j t}$ & 1270 & 9507 & 22,431 & 0 & 188,447 \\
GDP $_{i t}$ & 1270 & $1.72 \mathrm{E}+12$ & $1.24 \mathrm{E}+12$ & $1.24 \mathrm{E}+12$ & $2.92 \mathrm{E}+12$ \\
GDP $_{j t}$ & 1270 & $8.38 \mathrm{E}+11$ & $2.14 \mathrm{E}+12$ & $7.09 \mathrm{E}+8$ & $1.74 \mathrm{E}+13$ \\
Tariff $_{i j t}$ & 1270 & 13.5 & 15.4 & 0 & 60.3 \\
Tariff_Applied $_{i j t}$ & 1270 & 10.3 & 15.6 & 0 & 60.3 \\
Border $_{i j}$ & 1270 & 0.06 & 0.23 & 0 & 1 \\
Distance $_{i j}$ & 1270 & 7194 & 4,912 & 473.7 & 18,884 \\
PS $_{i j}$ & 1270 & 1.25 & 0.34 & 1 & 2.7 \\
\hline
\end{tabular}


selection bias (Heckman 1979). We estimate the gravity model using the Poisson Pseudo Maximum Likelihood (PPML) estimator which takes into account the heteroskedasticity of data and zero trade.

\section{Results and discussion}

This section provides the main results of our empirical estimations on the whole sample (see Table 2) and by exporting countries (see Table 3). We test various alternatives of Eq. 2 which corresponds to model (1) in Table 2 Model (2) replicates Eq. 2 but without considering the GDPs to test the stability of results. In both specifications, we control for exporter and/or importer and time fixed effects. Model (3) replicates model (1) but adds a dummy exporter equals to 1 if exporter is France and 0 for Chile and an

Table 2 Results of the PPML estimator on the whole sample

\begin{tabular}{|c|c|c|c|c|}
\hline & $X_{i j t}$ & $X_{i j t}$ & $X_{i j t}$ & $X_{i j t}$ \\
\hline & (1) & (2) & (3) & (4) \\
\hline $\ln G D P_{i t}$ & $\begin{array}{l}1.02^{* * * *} \\
(0.17)\end{array}$ & & $\begin{array}{c}1.02^{* * *} \\
(0.17)\end{array}$ & $\begin{array}{l}0.62^{* * *} \\
(0.03)\end{array}$ \\
\hline $\ln G D P_{j t}$ & $\begin{array}{c}0.34 \\
(0.26)\end{array}$ & & $\begin{array}{c}0.35 \\
(0.25)\end{array}$ & $\begin{array}{c}0.52 \\
(0.42)\end{array}$ \\
\hline InDistance $_{i j}$ & $\begin{array}{c}-1.41^{* * *} \\
(0.13)\end{array}$ & $\begin{array}{c}-1.41^{* * *} \\
(0.13)\end{array}$ & $\begin{array}{c}-1.21^{* * *} \\
(0.12)\end{array}$ & $\begin{array}{c}-1.75^{* * *} \\
(0.11)\end{array}$ \\
\hline InApplied_Tariff $f_{j t}$ & $\begin{array}{c}0.04 \\
(0.07)\end{array}$ & $\begin{array}{c}0.04 \\
(0.08)\end{array}$ & $\begin{array}{l}0.07 \\
(0.07)\end{array}$ & $\begin{array}{c}-0.55^{* * *} \\
(0.05)\end{array}$ \\
\hline Border $_{i j}$ & $\begin{array}{l}0.46^{* *} \\
(0.17)\end{array}$ & $\begin{array}{l}0.46^{* *} \\
(0.18)\end{array}$ & $\begin{array}{l}0.44^{* *} \\
(0.17)\end{array}$ & $\begin{array}{c}-0.50^{* * *} \\
(0.15)\end{array}$ \\
\hline$P S_{i j}$ & $\begin{array}{l}1.68^{*} \\
(0.82)\end{array}$ & $\begin{array}{c}1.65 \\
(0.85)\end{array}$ & $\begin{array}{c}6.92^{* * *} \\
(0.95)\end{array}$ & $\begin{array}{c}-4.11^{* * *} \\
(1.18)\end{array}$ \\
\hline Dummy $_{i}$ & & & $\begin{array}{c}5.82^{* * * *} \\
(1.11)\end{array}$ & \\
\hline$P S_{i j} * D u m m y_{i}$ & & & $\begin{array}{c}-7.33^{* * *} \\
(0.75)\end{array}$ & \\
\hline Dummy $_{A A}$ & & & & $\begin{array}{l}-2.52 \\
(1.55)\end{array}$ \\
\hline Dummy $_{A M}$ & & & & $\begin{array}{l}-4.21^{*} \\
(1.67)\end{array}$ \\
\hline DummyEU & & & & $\begin{aligned}- & 24.12^{* * *} \\
& (2.97)\end{aligned}$ \\
\hline Dummy $_{A F}$ & & & & $\begin{array}{l}3.74 \\
(2.57)\end{array}$ \\
\hline$P S_{i j} * D u m m y_{A A}$ & & & & $\begin{array}{c}2.14 \\
(1.22)\end{array}$ \\
\hline$P S_{i j} * D_{\text {Dummy }}$ AM & & & & $\begin{array}{c}2.56 \\
(1.33)\end{array}$ \\
\hline$P S_{i j} * D{ }^{\prime} m m y_{E U}$ & & & & $\begin{array}{c}20.03^{* * *} \\
(2.56)\end{array}$ \\
\hline$P S_{i j} * D_{\text {Dummy }}$ & & & & $\begin{array}{l}-3.33 \\
(2.12)\end{array}$ \\
\hline$f e_{i}$ & Yes & Yes & No & Yes \\
\hline$f e_{j}$ & Yes & Yes & Yes & No \\
\hline$f e_{t}$ & Yes & Yes & Yes & Yes \\
\hline $\begin{array}{l}\text { Observations } \\
\text { Adjusted } R^{2}\end{array}$ & $\begin{array}{l}1269 \\
0.91\end{array}$ & $\begin{array}{l}1270 \\
0.89\end{array}$ & $\begin{array}{l}1269 \\
0.91\end{array}$ & $\begin{array}{l}1269 \\
0.60\end{array}$ \\
\hline
\end{tabular}

Standard errors in parentheses. Significance level ${ }^{*} p<0.10,{ }^{* *} p<0.05,{ }^{* * *} p<0.01$ 
Table 3 Results of the PPML estimator by exporter

\begin{tabular}{|c|c|c|c|c|}
\hline & $\begin{array}{l}\ln X_{i j t} \\
i=\text { France }\end{array}$ & $\begin{array}{l}\ln X_{i j t} \\
i=\text { France }\end{array}$ & $\begin{array}{l}\ln X_{i j t} \\
i=\text { Chile }\end{array}$ & $\begin{array}{l}\ln X_{i j t} \\
i=\text { Chile }\end{array}$ \\
\hline \multirow[t]{2}{*}{$\overline{\ln G D P_{j t}}$} & $0.76^{* * *}$ & $0.67^{* * *}$ & $0.57^{* * *}$ & $0.59^{* * *}$ \\
\hline & $(0.04)$ & $(0.05)$ & $(0.02)$ & $(0.02)$ \\
\hline \multirow[t]{2}{*}{ InDistance $_{i j}$} & $-0.96^{* * *}$ & $-0.82^{* * *}$ & $-0.83^{* * *}$ & $-0.75^{* * *}$ \\
\hline & $(0.11)$ & $(0.09)$ & $(0.10)$ & $(0.082)$ \\
\hline \multirow[t]{2}{*}{ InApplied__Tariff ${ }_{i j t}$} & -0.11 & $-0.15^{*}$ & $-0.46^{* * *}$ & $-0.45^{* * *}$ \\
\hline & $(0.06)$ & $(0.06)$ & $(0.054)$ & $(0.05)$ \\
\hline \multirow[t]{2}{*}{ Border $_{i j}$} & $-0.65^{* * *}$ & & $-0.42^{* *}$ & \\
\hline & $(0.16)$ & & $(0.16)$ & \\
\hline \multirow[t]{2}{*}{$P S_{i j}$} & $-3.21^{* * *}$ & $-2.76^{* * *}$ & $-1.86^{* * *}$ & $-1.98^{* * *}$ \\
\hline & $(0.84)$ & $(0.75)$ & $(0.32)$ & $(0.35)$ \\
\hline Observations & 780 & 780 & 489 & 489 \\
\hline$R^{2}$ & 0.74 & 0.60 & 0.62 & 0.61 \\
\hline$f e_{t}$ & Yes & Yes & Yes & Yes \\
\hline
\end{tabular}

interaction term between the $P S$ and the dummy exporter. It does not control for country $i$ fixed effect. Finally, model (4) replicates Eq. (2) but adds an interaction between the PS and the Dummyreg, see Eq. (4).

When both exporters are considered jointly (Table 2 Models 1 and 2), the coefficients of the GDPs, Distance and Border have the expected signs, the beta of Applied_Tariff is not significant and the coefficient of the PS is positive and significant in Model (1), positive but not significant in Model (2). The average effect of the PS is nil (or very small: in Model (1) the impact of a 0.1 increase in the $P S$ would impact trade by US\$ 0.168 ) or it is captured by the country $i$ fixed effect.

When we introduce in our estimation, an interaction term between the exporting countries dummy and the PS (Model 3), we are able to separate the effects for each exporter. The beta coefficient for the Dummy $=1$ (i.e. France) indicates that if there is no sanitary constraint then France's trade would be US $\$ 5.82$ higher than Chile's. But for the average PS of 1.25 the interaction coefficient shows that the gap between France and Chile will be $[5.82+(-7.33 \times 1.25)]=-3.4$ US\$. This result means that for a same destination, Chile is more capable than France to face an increase of the $P S$ which can even give it a competitive advantage. This counterintuitive result is in line with the literature on SPS barriers to trade (see for instance, (Drogue and DeMaria 2012; Ferro et al. 2015; DeMaria and Drogue 2017) and suggests that instead of being an obstacle to trade, regulations can have a positive (or at least a non-negative) impact on trade for an experienced exporter as Chile able to adapt itself more easily to a tightening of phytosanitary requisites.

The last specification (Model 4) interacts a dummy region with the variable PS. It gives us information on the direction of the impact according to five world's regions: $A A$ (Australia and Asia), $A F$ (Africa), $A M$ (America), $E U$ (Europe), $W A$ ("Western" Asia). The omitted region is WA. The coefficients of the betas for GDP are positive. Distance and Applied_Tariff are negative and significant, Border is 
unexpectedly negative and significant. The coefficient of PS is negative (-4.1) meaning that for the omitted destination $W A$, an increase of sanitary constraints would have a negative effect on apples trade from both exporters. The betas of Dummy reg are significant and negative for region $A M$ and $E U$ meaning that the absence of sanitary constraint would have a negative effect on apples trade towards these regions and would benefit region $W A$. Interaction is only significant for $E U$ indicating that the effect of the PS may depend on the region of destination. Sanitary constraints do not affect all destinations in the same way. The destination more impacted by the $P S$ is $E U$ certainly because it affects more French than Chilean producers. The average $P S$ of 1.25 does not affect destinations $A A, A M$ or $A F$ compared to omitted region WA but has a positive impact on trade towards $E U$ of $[-24.12+(20.03 \times 1.25)]=0.9$ US\$.

We also ran our estimations on each country considered separately (see Table 3 ).

Table 3 shows that the coefficients of the GDP as expected are positive and significant suggesting that the size of the market of destination is important. Distance is negative for both France and Chile. The betas of Applied_Tariff are negative particularly for Chile. This is not surprising as the main market of France is the European Free Trade Area. The coefficient for Border is unexpectedly negative for both exporters. When we split the sample and perform the estimations on each exporter separately, the coefficients of the PS, which captures the effects of phytosanitary management regulations on the trade of each exporter, are negative and statistically significant for both countries. This supports result of Model 3 which concludes of a lesser impact of the PS on Chile compared to France. This suggests that pest-risk management measures increase the cost of trade for both exporters independently in accessing foreign markets and act as a barrier to trade of apples from France or Chile. But the impact is mitigated for Chile.

\section{Conclusion}

Our goal was to provide an empirical analysis of the key role of phytosanitary protocols for pests and diseases management on apples trade from France and Chile. We are interested in analysing these two countries because they are great apple exporters with different geographical, economic and social characteristics.

In a context of trade liberalisation, these protocols may be used in order to protect domestic market and domestic industries from undesirable foreign competitors. A country can raise requirements such that only few importers may have the capability to comply with the standards. That was the cause of a long-lasting dispute between the USA and Japan over Fuji apples (Calvin and Krissoff 1998; Calvin et al. 2008). Even if unintentionally, regulatory divergence often results in trade barriers and the impact it has on trade depends on their impact on supply and/or demand (Swinnen and Vandemoortele 2009; Marette and Beghin 2010; Swinnen and Vandemoortele 2011).

In this article, we introduced a restrictiveness index able to capture each dimension of requirements in pest and plagues management imposed to French and Chilean apples exporters by their trading partners in a gravity model. This score allows a 
hierarchy of destinations in terms of regulatory stringency. The estimation of the model gives the size of the impact of the pest risk management measures on trade from both exporters.

From a policy perspective, we have investigated whether or not these phytosanitary protocols have been effective in hampering exports of apples from France and Chile. The findings of this study show that the impact of requirements in pests and plagues management is greater for French exporters than Chilean exporters, suggesting that French producers need to make a greater effort to comply with the phytosanitary requirements imposed by the importing countries. France and Chile do not face significant differences in terms of phytosanitary restrictions when exporting to the same destination. However, France and Chile apply different regulatory restriction. France belongs to the EU group which is less demanding than Chile which belongs to the group of countries applying more complex protocols (DeMaria et al. 2018): 14). When a country adopts complex sanitary protocols, its producers benefit from spillovers when exporting towards demanding destinations (Vigani et al. 2012; Ragasa et al. 2017). The same is true when producers decide to export towards countries imposing more complex regulations as it is the case for Chile.

But not all producers benefit equally from these spillovers. The example of Chile and France shows that Chile, whose producers are more dynamic and export-oriented, are more capable to take advantage of the complexity of the protocols. This is why public authorities have a role to play in reducing regulatory divergences. Exporting countries' public authorities should implement strategies to help their producers to comply with foreign regulations. They have several public policy options at hand among which harmonisation, equivalence or mutual recognition, but their success depends on many factors such as the extent of the divergence, the interests at stake or the institutional capacity of the nations to negotiate bilateral agreements (Zezza et al. 2018; Lubello et al. 2019).

\section{Appendix}

Table 4 Non-tariff measure classification by chapter

\begin{tabular}{|c|c|c|}
\hline \multirow[t]{3}{*}{ Imports } & $\begin{array}{l}\text { Technical } \\
\text { measures }\end{array}$ & $\begin{array}{l}\text { A Sanitary and phytosanitary measures } \\
\text { B Technical barriers to trade } \\
\text { C Pre-shipment inspection and other formalities }\end{array}$ \\
\hline & $\begin{array}{l}\text { Non-technical } \\
\text { measures }\end{array}$ & $\begin{array}{l}\text { D Contingent trade-protective measures } \\
\text { E Non-automatic licensing, quotas, prohibitions, and quantity-control mea- } \\
\text { sures other than for SPS or TBT reasons } \\
\text { F Price-control measures, including additional taxes and charges. } \\
\text { G Finance measures } \\
\text { H Measures affecting competition } \\
\text { I Trade-related investment measures } \\
\text { J Distribution restrictions } \\
\text { K Restrictions on post-sales services } \\
\text { L Subsidies (excluding export subsidies under P7) } \\
\text { M Government procurement restrictions } \\
\text { N Intellectual property } \\
\text { O Rules of origin }\end{array}$ \\
\hline & Exports & P Export-related measures \\
\hline
\end{tabular}


Table 5 Dimensions and grades of the phytosanitary requirements and underlying regulations

\begin{tabular}{|c|c|}
\hline Dimension & Values \\
\hline Territorial restriction/QO restriction & $\begin{array}{l}0 \text { (No restriction) } \\
1 \text { (Yes restriction) } \\
2 \text { (Ban) }\end{array}$ \\
\hline Agreement & $\begin{array}{l}0 \text { (No agreement needed) } \\
1 \text { (Agreement on pre-listing) } \\
2 \text { (Agreement on yearly check) } \\
3 \text { (Ban) }\end{array}$ \\
\hline Import permission & $\begin{array}{l}0 \text { (No IP needed) } \\
1 \text { (The IP has been negotiated) } \\
2 \text { (The IP has not been negotiated) } \\
3 \text { (Ban) }\end{array}$ \\
\hline Phytosanitary certificate & $\begin{array}{l}0 \text { (No PC) } \\
1 \text { (The PC has been negotiated) } \\
2 \text { (The PC is under negotiation) } \\
3 \text { (The PC is non-official) } \\
4 \text { (Ban) }\end{array}$ \\
\hline Pre-inspection & $\begin{array}{l}0 \text { (No pre-inspection) } \\
1 \text { (Pre-inspection is required) } \\
2 \text { (Ban) }\end{array}$ \\
\hline Pre-clearance & $\begin{array}{l}0 \text { (No pre-clearance) } \\
1 \text { (Pre-clearance is required) } \\
2 \text { (Ban) }\end{array}$ \\
\hline Pre-cold treatment/fumigation & $\begin{array}{l}0 \text { (No treatment needed) } \\
1 \text { (Treatment needed) } \\
2 \text { (Ban) }\end{array}$ \\
\hline Cold treatment & $\begin{array}{l}0 \text { (No cold treatment) } \\
1 \text { (In transit cold treatment) } \\
2 \text { (At arrival cold treatment) } \\
3 \text { (Ban) }\end{array}$ \\
\hline Inspection at arrival & $\begin{array}{l}0 \text { (No inspection at arrival) } \\
1 \text { (Inspection at arrival) } \\
2 \text { (Ban) }\end{array}$ \\
\hline Total requirements & 24 (maximum requirements) \\
\hline
\end{tabular}

Source: DeMaria et al. (2018)

Table 6 List of countries and regions

\begin{tabular}{|c|c|}
\hline $\begin{array}{l}\text { Australia and Asia } \\
\text { (AA) }\end{array}$ & $\begin{array}{l}\text { Australia, Bangladesh, China, Hong Kong, India, Indonesia, Japan, Malaysia, } \\
\text { Maldives, Singapore, South Korea, Sri Lanka, Taiwan, Thailand, Viet Nam }\end{array}$ \\
\hline Africa (AF) & $\begin{array}{l}\text { Algeria, Angola, Cote d'Ivoire, Djibouti, Egypt, Eq. Guinea, Ethiopia, Guinea, Kenya, Libya, } \\
\text { Mauritania, Morocco, Nigeria, Seychelles, South Africa, Sudan, Togo, Tunisia, Uganda }\end{array}$ \\
\hline America (AM) & $\begin{array}{l}\text { Bolivia, Brazil, Canada, Colombia, Costa Rica, Dominican Republic, Ecuador, El Salvador, } \\
\text { Guatemala, Honduras, Mexico, Panama, Peru, United States of America, Uruguay, } \\
\text { Venezuela }\end{array}$ \\
\hline Europe (EU) & $\begin{array}{l}\text { Austria, Belgium, Bulgaria, Cyprus, Czech Republic, Denmark, Estonia, Finland, France, } \\
\text { Germany, Greece, Hungary, Iceland, Ireland, Italy, Latvia, Lithuania, Luxembourg, Malta, } \\
\text { Mayotte, New Caledonia, Netherlands, Norway, Poland, Portugal, Romania, Slovenia, Spain, } \\
\text { Sweden, Switzerland, United Kingdom }\end{array}$ \\
\hline "Western" Asia (WA) & $\begin{array}{l}\text { Bahrain, Georgia, Iran, Israel, Jordan, Kazakhstan, Kuwait, Oman, Qatar, Russia, Saudi Arabia, } \\
\text { Turkey, United Arab Emirates }\end{array}$ \\
\hline
\end{tabular}




\section{Abbreviations}

ANPP: Association Nationale Pommes Poires; APHIS: Animal and Plant Health Inspection Service; CEPII: Centre d'Etudes Prospectives et d'Informations Internationales; EU: European Union; GDP: Gross Domestic Product; ha: Hectares; HACCP: Hazard Analysis Critical Control Point; IPPC: International Plant Protection Convention; MAcMap: Market Access Map; MRL: Maximum residue levels; NTM: Non-Tariff Measures; PPML: Poisson pseudo maximum likelihood; PRA: Pest risk analysis; PS: Phytosanitary score; SPS: Sanitary and phytosanitary; UNCTAD: United Nations Conference on Trade and Development; USDA: United States Department of Agriculture; WTO: World Trade Organization

\section{Acknowledgements}

We thank the participants of the Sustain'Apple project for their comments.

\section{Authors' contributions}

PL and FD gathered the data. FD performed the econometric modelling. FD and SD analysed the data and wrote the first draft of the manuscript. All the authors interpreted the results. PL helped to draft the manuscript and made critical comments. SD conceived, designed and coordinated the study and had the primary responsibility for final content. All the authors read and approved the final manuscript.

\section{Funding}

This work has been financially supported by the French Agency of Research (ANR) under the project Sustain'Apple ANR-13-ALID-004.

\section{Availability of data and materials}

Data and material are available upon request to the corresponding author.

\section{Declarations}

Ethics approval and consent to participate

Not applicable.

\section{Consent for publication}

Not applicable.

\section{Competing interests}

The authors declare that they have no competing interests.

\section{Author details}

${ }^{1}$ CREA-PB, Rome, Italy. ${ }^{2}$ UMR MoISA, Univ Montpellier, CIRAD, CIHEAM-IAMM, INRAE, Institut Agro, 2 place

Pierre-Viala-Bât. 26, 34060 Montpellier Cedex 2, France.

Received: 26 July 2019 Revised: 3 August 2020

Accepted: 21 May 2021 Published online: 10 June 2021

\section{References}

Anderson JE (2011) The gravity model. Annu Rev Econ 3(1):133-160. https://doi.org/10.1146/annurev-economics-111809-12 5114

APHIS USDA (2014) Treatment Manual

Baldwin R, Taglioni D (2006) Gravity for dummies and dummies for gravity equations. National Bureau of Economic Research WP 12516. https://doi.org/10.3386/w12516

Beghin JC (2017) Nontariff Measures and International Trade. World Sci. https://doi.org/10.1142/10150

Beghin JC, Bureau J-C (2001) Quantitative policy analysis of sanitary, phytosanitary and technical barriers to trade. Econ Int 87: $107-130$

Burger M, van Oort F, Linders G-J (2009) On the specification of the gravity model of trade: zeros, excess zeros and zeroinflated estimation. Spatial Econ Anal 4(2):167-190. https://doi.org/10.1080/17421770902834327

Cadot O, Gourdon J (2014) Assessing the price-raising effect of non-tariff measures in Africa. J Afr Econ 23(4):425-463. https:// doi.org/10.1093/jae/eju007

Cadot O, Munadi E, Yan Ing L (2015) Streamlining non-tariff measures in ASEAN: the way forward. Asian Econ Papers 14(1): 35-70. https://doi.org/10.1162/ASEP_a_00315

Calvin L, Krissoff B (1998) Technical barriers to trade: a case study of phytosanitary barriers and U.S.-Japanese Apple Trade. J Agric Resource Econ 23:351-366

Calvin L, Krissoff B, Foster W (2008) Measuring the costs and trade effects of phytosanitary protocols: A U.S.-Japanese apple example. Rev Agric Econ 30(1):120-135. https://doi.org/10.1111/j.1467-9353.2007.00395.x

Carrère M, DeMaria F, Drogue S (2018) Maximum residual levels of pesticides and public health: best friends or faux amis? Agric Econ 49(1):111-118. https://doi.org/10.1111/agec.12399

Codron JM, Pavez I (2018) La gestion des risques SPS dans la filière d'exportation chilienne : une expérience riche d'enseignements

Crivelli P, Groeschl J (2016) The impact of sanitary and phytosanitary measures on market entry and trade flows. World Econ 39(3):444-473. https://doi.org/10.1111/twec.12283

De Benedictis L, Taglioni D (2011) The gravity model in international trade. In: De Benedictis L, Salvatici L (eds) The Trade Impact of European Union Preferential Policies: An Analysis Through Gravity Models. Springer, Berlin, Heidelberg, pp 5589. https://doi.org/10.1007/978-3-642-16564-1_4 
de Frahan BH, Vancauteren M (2006) Harmonisation of food regulations and trade in the Single Market: evidence from disaggregated data. Eur Rev Agric Econ 33(3):337-360. https://doi.org/10.1093/eurrag/jbl015

DeMaria F, Drogue S (2017) EU trade regulation for baby food: protecting health or trade? The World Economy 40(7):14301453. https://doi.org/10.1111/twec.12434

DeMaria F, Lubello P, Drogue S (2018) Measuring the complexity of complying with phytosanitary standard: the case of French and Chilean fresh apples. Bio-based Appl Econ 7:39-58-39-58. https://doi.org/10.13128/BAE-24047

Devadoss S, Sridharan P, Wahl T (2009) Effects of trade barriers on U.S. and world apple markets. Can J Agric Econ 57(1):5573. https://doi.org/10.1111/j.1744-7976.2008.01138.x

Drogue S, DeMaria F (2012) Pesticide residues and trade, the apple of discord? Food Policy 37(6):641-649. https://doi.org/10.1 016/j.foodpol.2012.06.007

Engler A, Nahuelhual L, Cofré G, Barrena J (2012) How far from harmonization are sanitary, phytosanitary and quality-related standards? An exporter's perception approach. Food Policy 37(2):162-170. https://doi.org/10.1016/j.foodpol.2011.12.003

FAO (2013) International Standards for Phytosanitary Measures 11 - Pest risk analysis for quarantine pests

Ferro E, Otsuki T, Wilson JS (2015) The effect of product standards on agricultural exports. Food Policy 50:68-79. https://doi. org/10.1016/j.foodpol.2014.10.016

Fischer R, Serra P (2000) Standards and protection. J Int Econ 52(2):377-400. https://doi.org/10.1016/S0022-1996(99)00058-6 Heckman JJ (1979) Sample selection bias as a specification error. Econometrica 47(1):153-161. https://doi.org/10.2307/1912352

Helpman E, Melitz M, Rubinstein Y (2008) Estimating trade flows: trading partners and trading volumes. Q J Econ 123(2):441487. https://doi.org/10.1162/qjec.2008.123.2.441

Lubello P, Codron J-M, Mathieu-Hurtiger V (2019) Les exportations françaises de pommes face à la contrainte du traitement au froid en transit. Un cas de dépendance de sentier institutionnel. Econ rurale n 370:29-46

Marette S, Beghin J (2010) Are standards always protectionist? Rev Int Econ 18(1):179-192. https://doi.org/10.1111/j.1467-93 96.2009.00856.x

Melo O, Engler A, Nahuehual L, Cofre G, Barrena J (2014) Do sanitary, phytosanitary, and quality-related standards affect international trade? Evidence from Chilean Fruit Exports. World Dev 54:350-359. https://doi.org/10.1016/j.worlddev.2013.1 0.005

Pimentel D (ed) (2011) Biological invasions: economic and environmental costs of alien plant, animal, and microbe species, 2nd edn. CRC Press. https://doi.org/10.1201/b10938

Pimentel D, Zuniga R, Morrison D (2005) Update on the environmental and economic costs associated with alien-invasive species in the United States. Ecol Econ 52(3):273-288. https://doi.org/10.1016/j.ecolecon.2004.10.002

Ragasa C, Thornsbury S, Joshi S (2017) Dynamics of EU food safety certification: a survival analysis of firm decisions. Agric Econ 5(1):11. https://doi.org/10.1186/s40100-017-0080-2

Roberts DH (1999) A framework for analyzing technical trade barriers in agricultural markets. U.S. Department of Agriculture, ERS

Silva JMCS, Tenreyro S (2006) The log of gravity. the review of economics and statistics 88:641-658. 88(4):641-658. https://doi. org/10.1162/rest.88.4.641

Swinnen J (2016) Economics and politics of food standards, trade, and development\#. Agric Econ 47(S1):7-19. https://doi. org/10.1111/agec.12316

Swinnen JFM, Vandemoortele T (2009) Are food safety standards different from other food standards? A political economy perspective. Eur Rev Agric Econ 36(4):507-523. https://doi.org/10.1093/erae/jbp025

Swinnen JFM, Vandemoortele T (2011) Trade and the political economy of food standards: trade and the political economy of food standards. J Agric Econ 62(2):259-280. https://doi.org/10.1111/j.1477-9552.2011.00294.x

UNCTAD (2012) International Classification of Non-Tariff measures, February 2012 version (UNCTAD/DITC/TAB/2012/2)

Vigani M, Raimondi V, Olper A (2012) International trade and endogenous standards: the case of GMO regulations. World Trade Rev 11(3):415-437. https://doi.org/10.1017/S1474745612000262

Zezza A, DeMaria F, Pupo D'Andrea MR, Swinnen J, Meloni G, Vandevelde S, Olper A, Curzi D, Raimondi V, Drogue S (2018) Research for AGRI committee - Agricultural trade: assessing reciprocity of standards. European Parliament, Policy Department for Structural and Cohesion Policies, Brussels

Zhao Z, Wahl T, Marsh T (2007) Economic effects of mitigating apple maggot spread. Can J Agric Econ 55:499-514 . doi: https://doi.org/10.1111/j.1744-7976.2007.00105.x, 4

\section{Publisher's Note}

Springer Nature remains neutral with regard to jurisdictional claims in published maps and institutional affiliations.

\section{Submit your manuscript to a SpringerOpen ${ }^{\circ}$ journal and benefit from:}

- Convenient online submission

- Rigorous peer review

- Open access: articles freely available online

- High visibility within the field

- Retaining the copyright to your article

Submit your next manuscript at $\mathbf{s p r i n g e r o p e n . c o m ~}$ 